Asignando claramente a la mujer una misión, Unruh desprende una consecuencia lógica de su visión del hombre en marcha hacia una huma. nidad pura. El orden nuevo en el dominio de la paz como en el de la moral, no puede nacer sino del amor del hombre y la mujer, dos términos de una misma unidad. La mujer que Unruh nos muestra en su obra es a la vez cuerpo y alma: está encargada de una misión intelectual, pero encarna también la belleza carnal y representa un tipo humano feliz de vivir y consciente de ser en el presente. Ella descubre una armonía del espíritu y de las fuerzas vitales. La mujer lleva al hombre la belleza, el sentido de lo divino en la vida, y le enseña a combatir por la verdad, por el espíritu. Unruh quiere arrancar al hombre de su enyugamiento a la gleba, de su sumisión a los Césares; debe ser un jefe lleno del sentimiento de sus propias fuerzas y consagrado al servicio del espíritu, una personalidad cósmica y no un esclavo perdido en la multitud. Unruh nos quiere enseñar a llegar a ser verdaderos hombres, en los que la vida y los actos sean santificados en Dios. El hombre debe apartarse de la vida animal y elevarse al plano de su responsabilidad humana, no huyendo de la vida sino tornándose maestro de ella. Unruh quiere hacer nacer una aristocracia social del espíritu que renuncie a todo ascetismo antinatural y que consagre la vida: una vida que no sea empujada por el instinto animal, que recaliente la sangre de una humanidad libre y fuerte. Tal es en su forma activa el pensamiento de Fritz von Unruh: nace de un sentimiento nuevo de la realidad y de la vida, y del miedo que siente el poeta frente a un conflicto en que están empeñados nuestros verdaderos valores espirituales; quiere, por la unión del hombre y la divinidad creadora, revelar a todos el nuevo imperio y con él, al hombre nuevo. La guerra y el amor no son para Unruh sino motivos, materiales arrancados a la realidad, para la construcción del templo donde encierra su revelación: el hombre nuevo $y$ el nuevo imperio-Dietrich e Irene-, la Humanidad y el Cosmos. De la realidad misma de la vida Unruh arranca para nosotros, una profecia del hombre nuevo; elabora una moral de acción, donde Logos y Eros unidos engendran un valor nuevo: una humanidad plena de fortaleza $y$ henchida de amor. Tal es la pura e inviolable misión moral que asume en la literatura Fritz von Unruh, hombre, poeta y profeta.

\section{Pintura Alemana DE HOY.}

En el mismo número de la Revue d'Allemagne, Eugenio Susini, conocido crítico de pintura, pasa una interesante revista a la pintura moderna, tomando como base para ella las últimas exposiciones de París y Berlín. Son los pintores de última hornada. Y despues de revisar someramente las obras expuestas de Charlotte Berend, que no tiene nada de la virtuosidad pictórica de su difunto marido Corinth de Kandisky, "que no ha encontrado su propio camino, influenciado por Klees; de Kleinschdmidt, cuyas telas expuestas no admira porque revelan la «limitación del colorido, uno solo: plata blanquecinos; de Krauskoopf, 'nombre conocido e interesantes; de Per Krogh, elleno de un encanto un poco decadente, de una finura y una fantasía exquisitas no desprovistas de poesías, afirma que ssi tuviera un premio que asignar lo daría a Schlichter, que expone dos telas de 
primera línea y donde se notan sus cualidades principales. $<$ Robusto, variado, matizado, con toda la gama de todos los colores, lleno de sugestión y acentuadamente dramático, Schlichter, colorista, juega con los colores y coloca en las mejillas de sus personajes un rojo tal como lo en- cuentra en su paleta y que llega a no desentonar en el conjunto.

Tales son los principales juicios de Susini sobre los pintores que en la hora actual se disputan en Alemania los favores del público y la consagración de los entendidos.Ariel. 